\title{
A Study on the Management Effectiveness and Problems of Tribal Colleges in Taiwan
}

\author{
Hsiao-Ming, Chang ${ }^{1}$, Yu-Hui, Lin², Yen-Chen, Huang ${ }^{3}$
}

\author{
${ }^{1}$ School of Physical Education, Putian University, China \\ ${ }^{2}$ School of Culture and Communication, Putian University, China \\ ${ }^{2}$ Department of Education and Human Potentials Development, National Dong Hwa University, Taiwan \\ ${ }^{3}$ Department of Marine Leisure and Tourism, Taipei University of Marine Technology, Taiwan
}

Received: 02 Dec 2020; Received in revised form: 28 Jan 2021; Accepted: 22 Feb 2021; Available online: 12 Mar 2021 C2021 The Author(s). Published by The Shillonga Publication. This is an open access article under the CC BY license (https://creativecommons.org/licenses/by/4.0/).

\begin{abstract}
The main purpose of this study is to analyze the development background and objectives of indigenous tribal colleges, and to understand the effectiveness and problems of its management in Taiwan. After SWOT analysis, the main findings are as follows: 1. Advantages: the unique culture of indigenous people is an opportunity for economic development. In addition, the protection of laws and regulations is the main advantage of tribal college. 2. Weakness: under the current economic system, the indigenous people are limited in land use, inconvenient transportation, inadequate agricultural technology, and unsmooth sales channels, which limit their economic development. 3. Threats: because the population flows to the city, the tribal people do not understand what kind of institution the tribal university is, and some of the funds have to be paid by the learners themselves, resulting in the low participation of the tribal people. Moreover, the units that handle tribal college are almost different every year, which affects the preservation of data. 4. Opportunities: the existence of tribal college also provides an opportunity for the inheritance and reconstruction of indigenous culture. Based on the above analysis, this study puts forward relevant suggestions for the management of tribal college.
\end{abstract}

Keywords - tribal college, adult education, continuing education, lifelong learning, indigenous people.

\section{INTRODUCTION}

Taiwan was colonized by Japan and the assimilation policy of the national government, which led to the serious loss of indigenous language and culture, and even faced the fate of disappearance. In view of this, the Taiwan Council of Indigenous People (TCIP) promotes all kinds of cultural revitalization work from bottom to top, hoping to save the endangered indigenous culture. In Taiwan's education system, for a long time, the education of Aboriginal people, whether within or outside the educational system, has been marginalized or attached. There has never been an education system with indigenous people as the main body [1]. Education is the best strategy to save indigenous culture from disappearing. The establishment of tribal university not only echoes the concept of lifelong learning and replicates the success of community college, but also enables Taiwan indigenous people to learn their own cultural courses rather than the mainstream education under national politics [2]. Therefore, the main purpose of this study is to analyze the development background and objectives of Taiwan indigenous tribal college, and to understand the effectiveness and problems of the management of the tribal college through qualitative research, hoping to provide reference for other tribes to promote adult education.

\section{LITERATURE REVIEW}

\subsection{Social background}

Taiwan's Community College movement started in 1998 with Wen-Shan Community College, the first community college in Taipei [3]. However, the promotion of the indigenous tribal college is due to the vigorous development of the community college in Taiwan. In 2001, the advocates of indigenous people selfconsciousness proposed the tribal college as a public issue of the year. The Ministry of Education and the TCIP jointly promoted the relevant counseling measures of the 
tribal college. In 2002, Taiwan's first indigenous tribal college was officially established in Taoyuan County. So far, there are 15 tribal colleges in Taiwan. The main purpose is to provide opportunities for indigenous people to learn for life and inherit their culture. The purpose is to establish their own ethnic identity and self-confidence through diversified learning, and to use the local mechanism of the tribe. Local elites select teachers to teach, so as to strengthen the tribal organization and inherit the mission of the traditional culture of the tribe. At present, the law source of the aboriginal tribal universities established in Taiwan's counties and cities is the "life-long learning law" formulated by the government in 2002. The first article states that this law is formulated to encourage life-long learning, promote life-long education, enhance learning opportunities, and improve the quality of the people. The definition of Community College in Article 3 (5) refers to the educational institutions that provide lifelong learning activities for community residents outside the formal education system, which are handled by or entrusted by the municipal or county (city) authorities directly under the central government. In 2003, the Ministry of Education of Taiwan promulgated Article 5 of the "detailed rules for the implementation of the lifelong learning law": "when the municipal or county (city) authorities directly under the central government set up or entrust community universities in accordance with Article 9 of this law, they shall make an annual budget. In addition, Article 28 of Chapter V of the "education law for indigenous peoples" promulgated in 1998 and revised in 2013 stipulates that local governments may set up or guide non-governmental organizations to set up promotion and education institutions for indigenous peoples to provide education for indigenous peoples, including (1) literacy education; (2) remedial or further education in schools at all levels; (3) ethnic skills, special skills or vocational training; (4) family education; (5) language education Cultural education; (6) tribal community education; (7) human rights education; (8) women's education; (9) other adult education. The expenses of the first and second subparagraphs of the preceding paragraph shall be fully subsidized by the central government, and other subparagraphs shall be subsidized as necessary. The above "Lifelong Learning Law" and "Indigenous People Education Law" provide the source of law and funding for the establishment of tribal college. But tribal college, like community college, is not a university (formal school). It's a special project, which needs to apply for relevant subsidy every year, and be handled by the elementary school in the tribe entrusted by the administration. The tribal college in the metropolitan area is also run by a primary school, which is equivalent to a community college. However, some metropolitan tribal college use church classrooms or integrated service centers for Aboriginal people to implement courses.

\subsection{Development goals of tribal college}

At the beginning of the founding of the tribal college in Taiwan, both scholars and indigenous social activists put forward relevant suggestions on the development goals of the tribal college. For example, Pu (2002) thinks that we should promote the learning environment of academic service and practice, combine the tribal knowledge and academic, widely invite the tribal knowledge elites and establish the tribal external information network [4]. Sun (2004) put forward the idea that tribal college should be the revival or recombination of indigenous tribes and culture, which combines local, tribal and folk resources to produce the education of collective traditional aboriginal culture and modern life [5]. Chen (2003) believes that tribal college exist to inherit ethnic life and reproduce tribal values. Tribal college deeply cultivate tribal education, create vitality for indigenous people, rebuild the dignity of indigenous ethnic groups and create a multicultural learning culture, forming a mutually beneficial relationship among tribes, industries and academic cultures [6]. Chen (2004) believes that the tribal college should create a tribal learning organization, practice the concept of lifelong learning, combine with the development of local industry, and support the tribal community-based education. The government also hopes to strengthen the organizational function of tribal college, provide lifelong learning courses for indigenous people, build a lifelong learning environment for indigenous people, and cultivate tribal development talents and modern citizens through the establishment of subsidization points for tribal college. For the development of tribal college, whether it is government policies or scholars' views, most think that we should start from the "tribal" point of view, combine the resources of the tribe, whether it is human or local, and build the cultural assets of the exclusive tribe, so that the tribe can show its subjectivity and promote the development of the tribe [7]. Gu Zong (2004) also concluded that the tribal community college takes "tribal regeneration" as the core, and includes four courses: "lifelong learning", "cultural growth", "tribal construction" and "ethical norms". Through diversified learning, we can build the self-identity and self-confidence of ethnic groups, use the teaching of tribal talents, strengthen the tribal organization, and inherit the traditional tribal culture [8]. Based on the suggestions of the above scholars and the "key points of subsidy for aboriginal tribal college" issued by the Taiwan government, we can find that the main purpose of promoting indigenous tribal universities is to develop aboriginal culture and wisdom, promote the innovation of 
aboriginal culture, cultivate talents and modern citizens in tribal communities, and build a lifelong learning environment for indigenous society.

\section{RESEARCH METHODOLOGY}

This study mainly uses three research methods for investigation, the first is literature analysis method, the second is observation method, the third is interview method.

\subsection{Literature analysis}

Through the websites of the TCIP and the Taiwan Ministry of Education, we can learn about the management of tribal college in various counties and cities, as well as the relevant information about the evaluation. Secondly, by referring to the research literature of tribal college, to understand the curriculum development of 15 counties and cities.

\subsection{Observation method}

In the second stage of this study, the researchers went to 15 counties and cities to find out the situation of local residents studying in tribal college.

\subsection{Interview method}

In the third stage of this study, the administrative staff, students and teachers in tribal college were interviewed. The outline of the interview is as follows:

(1) What are the courses in your tribal college?

(2) What advantages do you think tribal college have in their development?

(3) What are the disadvantages in the development of tribal college?

(4) What do you think is the threat to the development of indigenous tribal college? And where is the opportunity?

In this study, after the interview, first of all, the interview data will be made into a verbatim draft, followed by a comprehensive literature analysis, as well as the results of the actual observation. In order not to cause the subjective judgment of the researchers, the researchers adopt the way of joint analysis, in the SWOT, in order to obtain a consistent consensus, and then write the results of the analysis.

\section{CURRICULUM PLANNING OF TRIBAL COLLEGE}

Due to the fact that the curriculum, an indispensable element of the school, is also tested by the reality, since the core value of the tribal college lies in the "tribe", there are not too many external regulations on the curriculum planning of the tribal college. As long as the application can be submitted before the course is started, and the course can be started after being approved by the TCIP. According to the research of Wang Jueqing (2015), the courses offered in Taiwan's tribal college are summarized as shown in Table 1 [9].

Table 1. The establish year and program of tribal college

\begin{tabular}{|c|c|c|}
\hline Location & Year & Programs / Courses \\
\hline $\begin{array}{l}\text { Taipei } \\
\text { City }\end{array}$ & 2004 & $\begin{array}{l}\text { Culture and language, art } \\
\text { program, digital media, industry } \\
\text { program, family and social } \\
\text { education, growth program. }\end{array}$ \\
\hline $\begin{array}{l}\text { New } \\
\text { Taipei } \\
\text { City }\end{array}$ & 2009 & $\begin{array}{l}\text { Industrial training, history and } \\
\text { culture, health movement, } \\
\text { community education, human } \\
\text { rights youth counseling, } \\
\text { information technology, gender } \\
\text { parenting education, industrial } \\
\text { management culture exploration, } \\
\text { language and literature, health } \\
\text { promotion and care. }\end{array}$ \\
\hline $\begin{array}{l}\text { Taoyuan } \\
\text { City }\end{array}$ & 2002 & $\begin{array}{l}\text { Industry program, natural } \\
\text { resources program, culture } \\
\text { program, culture program, tribal } \\
\text { research program }\end{array}$ \\
\hline $\begin{array}{l}\text { Hsinchu } \\
\text { County }\end{array}$ & 2003 & $\begin{array}{l}\text { Culture program, community } \\
\text { program, industry program, } \\
\text { natural resources program, tribal } \\
\text { research program }\end{array}$ \\
\hline $\begin{array}{l}\text { Miaoli } \\
\text { County }\end{array}$ & 2002 & $\begin{array}{l}\text { Indigenous language, indigenous } \\
\text { traditional culture, tribal industry } \\
\text { and life skills }\end{array}$ \\
\hline $\begin{array}{l}\text { Taichung } \\
\text { City }\end{array}$ & 2007 & $\begin{array}{c}\text { Indigenous language, tribal art, } \\
\text { life skills }\end{array}$ \\
\hline $\begin{array}{l}\text { Nantou } \\
\text { County }\end{array}$ & 2002 & $\begin{array}{l}\text { Indigenous language culture, art } \\
\text { industry, science and technology, } \\
\text { leisure services }\end{array}$ \\
\hline $\begin{array}{l}\text { Chiayi } \\
\text { County }\end{array}$ & 2004 & Tribal art program \\
\hline $\begin{array}{l}\text { Tainan } \\
\text { City }\end{array}$ & 2002 & $\begin{array}{l}\text { Indigenous language and } \\
\text { traditional culture }\end{array}$ \\
\hline $\begin{array}{l}\text { Kaohsiung } \\
\text { City }\end{array}$ & 2003 & $\begin{array}{c}\text { Indigenous culture, life } \\
\text { knowledge and ability, industrial } \\
\text { development, environmental } \\
\text { protection and ecology }\end{array}$ \\
\hline $\begin{array}{l}\text { Pingtung } \\
\text { County }\end{array}$ & 2002 & $\begin{array}{l}\text { Culture, community and personal } \\
\text { growth, industry, natural } \\
\text { resources, tribal studies }\end{array}$ \\
\hline
\end{tabular}




\begin{tabular}{|c|c|c|}
\hline $\begin{array}{c}\text { Keelung } \\
\text { City }\end{array}$ & 2001 & $\begin{array}{c}\text { Indigenous language, traditional } \\
\text { culture and life knowledge }\end{array}$ \\
\hline $\begin{array}{c}\text { Yilin } \\
\text { County }\end{array}$ & 2002 & $\begin{array}{c}\text { Culture, industry, natural } \\
\text { resources and tribal studies }\end{array}$ \\
\hline $\begin{array}{c}\text { Hualien } \\
\text { County }\end{array}$ & 2002 & $\begin{array}{c}\text { Indigenous language, Aboriginal } \\
\text { history and culture, Aboriginal } \\
\text { industrial management, } \\
\text { Aboriginal ecological knowledge } \\
\text { and tribal community }\end{array}$ \\
\hline $\begin{array}{c}\text { Taitung } \\
\text { County }\end{array}$ & 2002 & $\begin{array}{c}\text { Ecology, science and technology, } \\
\text { ethnic culture, art and society }\end{array}$ \\
\hline
\end{tabular}

According to the results in Table 1, it can be found that the courses of tribal college can be divided into tribal and ecological construction course, aboriginal culture course, industrial development course, life knowledge and ability course, etc. The results of the research in the tribal college show that the courses offered are more diversified, including: indigenous language and culture, industrial development, information education, community utility, functional license, traditional songs, handicrafts, weaving, pottery making, hunting traditional bow and arrow making, etc.

On the whole, the courses of tribal college can be summarized as follows: (1) cultural courses: courses planned according to the traditional culture, language and lifestyle of all ethnic groups, providing learning contents for lifelong learning and cultural inheritance of ethnic groups; (2) life courses: medical and health, legal knowledge, personal growth, strengthening physical fitness, developing high-quality life, and improving the quality of life; (3) Industry courses: Catering certification, agricultural courses, etc. According to the industrial development orientation of each tribe, the courses of traditional craft training and technical and vocational training should be planned for the tribe people, and relevant courses should be set up in each region to facilitate the study and employment of the tribe people; (4) natural and ecological courses: natural resources management, understanding of wild animals and plants, ecological environment and other courses; (5) tribal construction courses: autonomy and tribal development, training of tribal talents, etc.

\section{SWOT ANALYSIS ON THE DEVELOPMENT OF TRIBAL COLLEGE}

The results of this part, mainly based on the results of the interview, will be the views of the interviewees, according to SWOT analysis, summarized as follows.

\subsection{Adaventage}

The unique culture of indigenous people is the foundation of cultural and creative industries. The development of cultural and creative industries is an opportunity for the economic development of indigenous people, and also provides a place for the development of tribal college. In addition, in terms of laws and regulations, Taiwan's Ministry of Education's "Lifelong Learning Law" and "Indigenous Education Law" provide the source of law and funding for the establishment of indigenous tribal college. According to Article 7 of the basic law of indigenous peoples, the government should protect the educational rights of indigenous peoples in the spirit of pluralism, equality and respect according to the will of indigenous peoples, and other relevant matters should be regulated by law. So basically, the establishment of indigenous tribal college, with the support of laws and regulations, has become one of its main advantages.

\subsection{Weakness}

Under the influence of Taiwan's current economic system and globalization, the indigenous people are in a weak position. The restrictions on land use, inconvenient transportation, inadequate agricultural technology and unsmooth sales channels limit the economic development of the indigenous people. The development of aboriginal cultural and creative industries is one of the main themes of most tribal college. Many courses related to cultural and creative industries are also offered. Although students can learn relevant technologies through the courses of tribal college. However, it failed to develop its own cultural and creative products in combination with the local culture, so that the curriculum could not be transformed into industrial development and the economic environment of the tribe could not be substantially improved. Because the indigenous areas are located in the border areas and lack of marketing channels, it is difficult to show the function of production and marketing. There are many excellent cultural and artistic workers or studios in the tribe. The products or services they produce often rely on competitions or public departments to hold exhibitions and sales fairs. It is obvious that their marketing channels are not well established. Tribal college takes cultural and creative industries as its main axis. There are many related courses in its courses, producing many products with indigenous characteristics, and building an information platform for product sales. However, product sales are not smooth. It is mainly due to the lack of marketing concepts and effective marketing strategies of the ethnic groups, and the lack of knowledge about indigenous culture among the general public. In order to make the products acceptable to consumers, more cultural transmission is needed. Although the tribal university has set up the tribal ecological tour, 
creative food, hand ceremony production and so on, it is a pity that at present, the development of tourism in the tribe still depends on the existing concept of tourism industry development, thinking about how to occupy a place in the scenic area where there are many tourists, selling indigenous products, and falling into the puzzle of economic benefits.

\subsection{Treat}

Interviewees pointed out that even though the government has introduced many policies and measures, they are still unable to cope with practical problems. Due to the outflow of population, most of the young people choose to live in the metropolitan area because of their professional needs, which makes it difficult to recruit talents for tribal work. The tribal people do not understand what kind of institution the tribal college is and what kind of substantial help it has given them. The students of tribal college are often those who have strong identification with ethnic culture, and they are not popular among all ethnic groups. Moreover, economic factors limit the number of students. Due to the instability of funding sources, it has become the biggest variable for the sustainable operation of tribal college.

In addition, due to economic factors, the tribe is faced with the problem of young people leaving the tribe, resulting in the fault of tribal language and the difficulty of recruiting outstanding young people to participate in tribal activities. As part of the funding of the tribal college is paid by the learners themselves, it is even more difficult for the indigenous groups who are in a low economic situation to recruit students. Due to the low degree of contact among the courses of tribal college and the lack of integrated resource system, it is difficult to achieve a common vision and attract tribal adults to study. However, the understanding of tribal college is low, resulting in the low participation of the people.

Because the tribal university is not a fixed school, it is usually a tribal primary school that uses the existing equipment to undertake the teaching work. Due to the difference of the organizers over the years, there is no record of the data and no transfer. In addition, the tribal university has never had a fixed school headquarters. The school headquarters moves with the entrusted units, which also affects the preservation of the data. Literature and works can record the history of tribal college. Relevant materials can be used as the inheritance of experience. It is a pity if they cannot be preserved.

In addition, the management of tribal college belongs to the category of local governments. Therefore, the relevant administrative norms are not unified according to the conditions, resources and cultural background of each county and city. The local government and the undertakers have a great influence on the management performance. Although there are specific organizations and special personnel in charge of the local governments, the special personnel still have other positions, and the business of tribal college is only a part of them. It often leads to the situation that the mind is more than the strength, and the business of a few undertakers can last for several years. As a result, the timeliness of the management of tribal college affairs is delayed, which affects the students' learning and school running performance.

\subsection{Opportunity}

Tribal college is a precious resource for indigenous people. Its existence also provides an opportunity for the inheritance and reconstruction of aboriginal culture. Language and culture are the basis of ethnic education. The curriculum combines the human and material resources of tribal groups, and condenses the learning will of ethnic groups. Tribal groups also include traditional youth organizations and church groups. Through the integration of resources, they can change the purpose of learning and improve the effectiveness of curriculum implementation. For example, the tribal harvest festival in Taitung is the most direct exhibition of curriculum achievements. The tribal youth follow the steps of the elders and retrieve the lost tribal songs word by word.

Since its inception in 2001, the tribal college has been gradually rekindling the spark of tribal regeneration through its local rooted courses and the efforts of people with insight who are determined to rebuild the tribal culture.

In the process of inheritance, it not only continues the life of the indigenous culture and history, but also gives the old people a chance to explain the story of the tribe again. At the same time, it stimulates the elders of the tribe to find self-confidence and dignity in life, and also enables the tribal people to construct their own history. The traditional learning mode of indigenous people is very similar to "apprenticeship". The family and tribe are the school of the indigenous people. The elder of the tribe is the teacher of life and school. The elements of dialogue, sacrifice, hunting, weaving, building houses and so on are the materials of daily life learning and an important way to maintain the ethical order of the elders and children. Through the cultural inheritance of family and tribe, personal learning, tribal life and clan life are closely linked, so that the vitality of tribal culture can continue. 


\section{CONCLUSION AND SUGGESTION}

\subsection{Conclusion}

This study found that in the process of promoting the revival of aboriginal culture, all the tribal universities experienced various setbacks and dilemmas. The lecturers or organizers of the tribal universities interviewed all agreed that the tribal learning course had significantly improved the self and family learning atmosphere and cultural identity of the tribal people. Through the construction and development of tribal traditional knowledge, the important elements of culture can be integrated into various aspects of industrial development, and the material basis for the survival of the aboriginal culture can be found, so as to achieve the mission of cultural inheritance more effectively.

However, this study also found that there are the following problems in running tribal college: (1) it is difficult to gather tribal consensus, and it is unable to formulate the curriculum of common needs of tribes. (2) (3) the learning achievement cannot be reflected in the improvement of living economy, resulting in the low willingness of tribal learning. (4) Due to the shortage of teachers, the schools have been run by elite tribes for a long time. (5) Lack of human resources, business development difficulties. (6) The source of funds mostly depends on government subsidies, which leads to the uncertainty of running a school.

Some of these problems are caused by the poor environment of the tribe, while others are caused by the operation strategy. The original knowledge system and values of indigenous tribes have always been an important force to maintain their traditional society. As a result of their long-term contact with the mainstream society, they gradually lose their original traditional knowledge and naturally lose their basis for maintaining social survival.

Therefore, the establishment of traditional knowledge in tribal college will gradually restore the values and life attitudes of the aboriginal society. Only then can we have the opportunity to use these elements to reconstruct a way of life belonging to the aborigines. Only in this way can we have the strength to interact with the mainstream capitalist society, because these elements can be transformed into the main characteristics of the tribal economy, and in the future, we can have the opportunity to continuously manage the indigenous tribal industry.

\subsection{Suggestion}

As the Taiwan Ministry of Education has implemented the teaching evaluation of tribal college, the management of school affairs has been improved. Therefore, based on the above findings, this study puts forward the following suggestions: (1) to cultivate learning leaders of each tribe, combine with tribal learning organizations, develop the common vision of the tribe through communication, develop the tribal industry, improve the style of the tribe, and improve the quality of life of tribal members. Let the cultivated learning leaders enter the tribal college as the teachers of promotion, so that the tribal culture and tradition can continue. (2) Use tradition to promote the extension of aboriginal culture and tribe, and integrate the original natural resources, value and positioning of related courses. For example, the concept of deep cultivation of tribal industry, the diversified development of tribes and so on. Through the curriculum design of benign communication, technology, skill training and sustainable development, we can cultivate talents, so that the people can get employment, service, development and aging in the local area, and not live a life far away from their hometown, wandering and discriminated against because of their work. (3) By inviting lecturers with practical operation experience in various fields to share the explanation of operation process and steps and the cultivation of plan writing, the administrative efficiency and curriculum planning ability can be improved.

\section{ACKNOWLEDGEMENTS}

This study was supported by a grant from National Social Science Foundation of China (No.18BMZ130).

\section{REFERENCES}

[1] Yuhani, Iskafut. (2002). The awakening and rejuvenation of indigenous peoples. Taiwan, Taipei: Vanguard Press.

[2] Dai, Ren-Jie (2002). A study of indigenous people's satisfaction with education policy. Master thesis, National Jinan International University. Taiwan: Nantou County.

[3] Chang, De-Yong. (2001). Community college: Theory and practice. Taipei: Normal University Library.

[4] Pu, Zhong-Cheng. (2002). The trend of native language teaching in Taiwan. Indigenous Education Quarterly, 25, 5671.

[5] Sun, Da-Chuan. (2004). The orientation and spirit of indigenous community university. Report on the results of the 1993 indigenous tribal community college practice seminar, pp.14-23. Taipei: Taiwan Council of Indigenous People.

[6] Chen, Zhi-Lie. (2003). On the idea of running tribal college. Indigenous Education Quarterly, 29, 137-142.

[7] Chen, Mei-Lin. (2004). The transformation of Indigenous Community University, the integration of tribal knowledge and industrial development. The Handbook of the seminar on resource integration and tribal learning sponsored by the Council of Indigenous Peoples of the Executive Yuan and edited by the Promotion Association of Taiwan Institute of Indigenous Peoples. 105-117。 
[8] Gu Zong, Kalefangan (2004). Visit and review of indigenous tribal community college in 1992. National Donghua University, Institute of Ethnic Development (Ed), Report on the results of the 1993 indigenous tribal community college practice seminar, pp.24-33.

[9] Wang, I-Chuqing (2015). A Study on the relationships between social support and learning satisfaction of tribal college students in Nantou County. Master's thesis, Master thesis, National Jinan International University. Taiwan: Nantou County. 